\title{
The Start-Up of Continuous Hydrogen Production Process by Anaerobic Fermentation of Food Waste and Glucose
}

\author{
Weijuan ZHU \\ College of Engineering and Technology \\ Tianjin Agricultural University \\ Tianjin, 300384, China \\ e-mail: 1490274166@qq.com \\ Yan GUO \\ College of Engineering and Technology \\ Tianjin Agricultural University \\ Tianjin, 300384, China \\ e-mail: 2210158564@qq.com
}

\author{
Xinyuan LIU \\ College of Engineering and Technology \\ Tianjin Agricultural University \\ Tianjin, 300384, China \\ e-mail: liuxinyuan11@163.com \\ Jingkun CUI \\ College of Engineering and Technology \\ Tianjin Agricultural University \\ Tianjin, 300384, China \\ e-mail: 1072991255@qq.com
}

\author{
Qi ZHANG \\ College of Engineering and Technology \\ Tianjin Agricultural University \\ Tianjin, 300384, China \\ e-mail: 2433352519@qq.com
}

\begin{abstract}
Continuous biohydrogen production process by anaerobic fermentation of glucose was successfully started-up and the average hydrogen yield of $68.6 \mathrm{ml} / \mathrm{g}$ carbohydrate $_{\text {removed }}$ was obtained. When the feedstock converted into the mixture of food waste and glucose, the highest hydrogen yield of $77.4 \mathrm{ml}-\mathrm{H}_{2} / \mathrm{g}-\mathrm{VS}_{\text {removed }}$ in average was achieved at the food waste proportion of $50 \%$. The biogas was not produced any more feeding sole food waste, indicating the failure in the start-up of biohydrogen production process by anaerobic fermentation of food waste by substrate acclimatization.
\end{abstract}

Keywords-hydrogen production; food waste; glucose, start-up

\section{INTRODUCTION}

Hydrogen is well-known as clear energy, which does not release greenhouse gas upon combustion. Besides, the combustion heat of hydrogen achieves $122 \mathrm{~kJ} / \mathrm{g}$, which is much higher than fossil fuels. Based on the global energy shortage and environmental pollution, the hydrogen production attracts more and more interest recently. However, the conventional hydrogen production methods are mainly energy intensive and cost ineffective, such as steam reforming, autothermal reforming, water gas shift, partial oxidation, and et al[1]. Moreover, in the traditional technologies, the raw material for hydrogen production could be directly used as fuels to provide energy. As one of the biological technologies, the dark fermentation process for hydrogen production is much more utilizable on the economic perspective, and much more efficient than other biological hydrogen production methods. Otherwise, the organic wastes could be used as fermentation substrate and converted into hydrogen by dark fermentation process.

Food waste is one of the main components in municipal wastes, and it contains great amount of organic matters, such as carbohydrate, protein and lipids. The spoilage of food waste would cause serious environmental problem. Hydrogen production from food waste by anaerobic dark fermentation process is good for the disposal and recycling of food waste. Hydrogen production from food waste had been developed for decades, and it was reported that the biohydrogen reactor was operated successful for 80 days in pilot scale[2]. Whereas, the hydrogen production process is susceptible to many influence factors, such as the temperature, $\mathrm{pH}$, seed sludge, hydraulic retention time (HRT), organic loading rate (OLR), metabolic products, and so on. The hydrogen production process must be precisely controlled to maintain the abundances and activities of hydrogen producing bacteria. The start-up in especial is the key stage to the long-term operation for continuous hydrogen production process, because the dominant microorganisms are selected by the operation conditions during the start-up stage. Batch start-up strategy is commonly used in continuous operation. Nevertheless, this strategy will be affected by nutrient concentrations, especially at the end hours of the batch cycle, which would result in a shift in the dominant strains in the reactor[3].

In this study, the continuous start-up strategy was applied in food waste fermentation process. Considering the adverse effects of raw microorganisms in food waste on hydrogen production, the hydrogen producing bacteria were firstly cultured by sole glucose and then gradually accommodated 
to food waste by increasing the proportion of food waste in substrate. This study investigated the hydrogen production characteristics of the cultured microorganisms feeding various proportions of glucose and food waste, and attempted to start up the biohydrogen production process from food waste by substrate acclimatization.

\section{MATERIALS AND METHODS}

\section{A. Reactor Design And Operation}

Continuous hydrogen production experiment was performed in a fermentation system composed of a 3.01 feedstock container, 5.01 fermentation reactor and a 1.51 sedimentation tank, which is shown in Figure 1. The fermentation reactor with working volume of 3.61 was continuously stirred. The temperature was maintained at $37^{\circ} \mathrm{C}$ and the $\mathrm{pH}$ of 5.5 was adjusted by $5 \mathrm{M} \mathrm{NaOH}$ and $1 \mathrm{M}$ $\mathrm{HCl}$ solution automatically. The feedstock of $6.2 \mathrm{l} / \mathrm{d}$ was pumped into fermentation reactor, the effluent and biogas was pressured into sedimentation tank, the sediment was recirculated into fermentation reactor at the flow rate of 1.0 $1 / d$ to supplement the hydrogen producing bacteria and the effluent was discharged. Thus, the HRT of fermentation reactor is $12 \mathrm{~h}$.
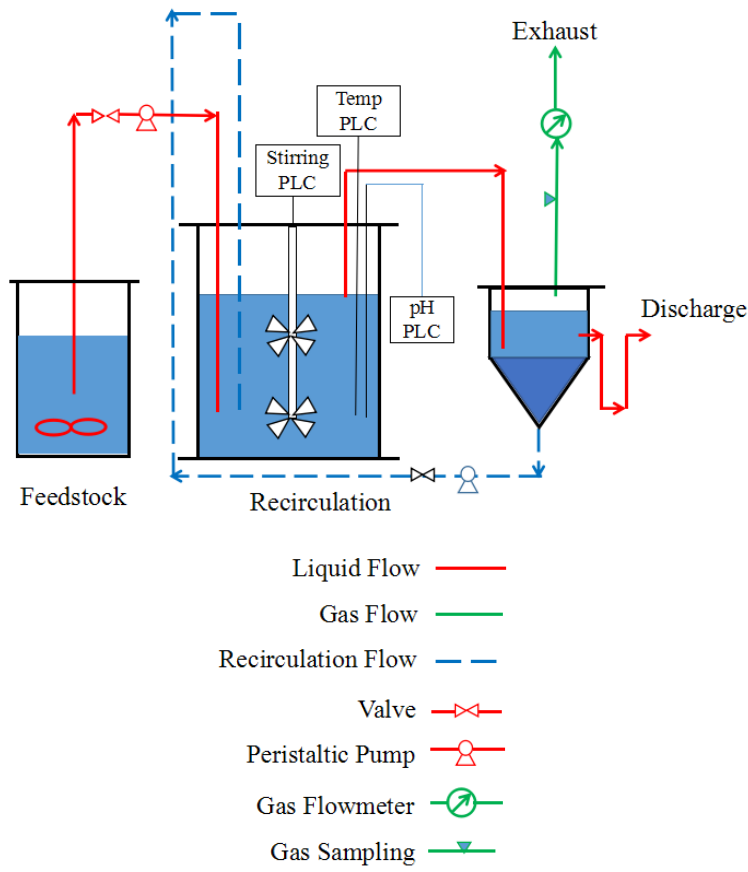

Figure 1. Anaerobic fermentative hydrogen production schematic diagram in continuous mode.

\section{B. Feedstock And Seed Sludge}

Based on the component of feedstock, the operation was divided into five phases. In the phase I (Start-up Phase), the feedstock was sole glucose with the concentration of about $30 \mathrm{~g} / \mathrm{l}$. The nutrient solution (per liter of feedstock, $5.24 \mathrm{~g}$ $\mathrm{NH}_{4} \mathrm{HCO}_{3}, 0.125 \mathrm{~g} \mathrm{~K}_{2} \mathrm{HPO}_{4}, 0.015 \mathrm{~g} \mathrm{MgCl}_{2} \cdot 6 \mathrm{H}_{2} \mathrm{O}, 0.025 \mathrm{~g}$ $\mathrm{FeSO}_{4} \cdot 7 \mathrm{H}_{2} \mathrm{O}, 0.005 \mathrm{~g}, \mathrm{NaHCO}_{3}, 0.125 \mathrm{mg} \mathrm{CoCl} \cdot 5 \mathrm{H}_{2} \mathrm{O}$, and $6.72 \mathrm{~g} \mathrm{CuSO}_{4} \cdot 5 \mathrm{H}_{2} \mathrm{O}$ ) was added into the fermentation reactor for bacterial growth during phase I[4].In the phase II to phase IV, the feedstock was the mixture of glucose and food waste, and the proportions of food waste were $0.25,0.5$ and 0.75 , respectively. In the phase $\mathrm{V}$, the feedstock was sole food waste. The VS content of feedstock was about $20 \mathrm{~g} / \mathrm{l}$ in the phase of II to phase V.

The seed sludge derived from anaerobic digester treating food waste was boiled for $30 \mathrm{~min}$ to inactive the hydrogen consuming bacterial and then cultured in the fermentation reactor feeding glucose and nutrient solution. The hydrogen producing seed sludge was enriched for 1 month, during which the HRT dropped from $2 \mathrm{~d}$ to $12 \mathrm{~h}$, and the glucose concentration gradually increased from $9 \mathrm{~g} / 1$ to $30 \mathrm{~g} / \mathrm{l}$. The analytical methods referred to author's another study[5].

\section{III.START-UP PERFORMANCE WITH GLUCOSE As FEEDSTOCK}

At the start-up phase (Phase I), the hydrogen production system was operated stably feeding glucose at OLR of 60 $\mathrm{g} / \mathrm{l} / \mathrm{d}$, the biogas production and main component content are shown in Figure 2. The average biogas production is $21.5 \mathrm{l} / \mathrm{d}$, and the hydrogen and carbon dioxide was the main components in biogas, accounting for $51.3 \%$ and $38.8 \%$ in average. However, few amount of methane (0.16\%) was detected in the biogas, which might be caused by the sediment recirculation. The sedimentation tank was demonstrated to be useful in the separation of sludge retention time and HRT, and thus preventing the loss of hydrogen producing bacteria and promoting the fermentation efficiency[6]. The VS of the recirculation sludge was 25.44$28.76 \mathrm{~g}-\mathrm{VS} / \mathrm{l}$. The average removal efficiency of soluble carbohydrate was $72.0 \%$, and the hydrogen yield of 68.6

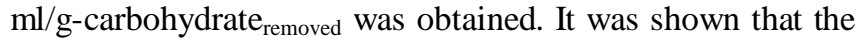
fermentation system was started up successfully according to the stable performance on the hydrogen yield and VS concentration. The appearance of fermentation broth turned white after the start up stage.

\section{Hydrogen Production From Co-FERMENTATION OF Food Waste And Glucose}

During the phase II to phase IV, the biogas was continuously produced and the dominant content was hydrogen and carbon dioxide. However, because of the variation in OLR (from $30 \mathrm{~g} / \mathrm{l} / \mathrm{d}$ to $20 \mathrm{~g} / \mathrm{l} / \mathrm{d}$ ) and the feedstock component (from sole glucose to $25 \%$ of glucose and $75 \%$ of food waste) in the initial of phase II, the biogas production and hydrogen content decreased to $1.32 \mathrm{l} / \mathrm{d}$ and $39.5 \%$, respectively. The influence of the great shock was partly repaired in the phase II, where the biogas production gradually increased to $6.45-6.90 \mathrm{l} / \mathrm{d}$, and the hydrogen content in biogas reached $50.1 \%-63.4 \%$. In phase III and phase IV, the biogas production and content were stable with respective hydrogen production of $3.71-\mathrm{H}_{2} / \mathrm{d}$ and $1.61-\mathrm{H}_{2} / \mathrm{d}$ in average. In phase $\mathrm{V}$, it was found that the biogas did not produced any more, indicating the failure in the start-up of anaerobic fermentation process from food waste by acclimatization from glucose to food waste. 
Figure 3 shows the hydrogen yield produced from per $\mathrm{VS}_{\text {removed }}$ and per $\mathrm{VS}_{\text {added }}$ in the phase II to phase IV. The hydrogen yield increased with food waste proportion in phase II and phase III and reached the highest yield of 77.4 $\mathrm{ml}-\mathrm{H}_{2} / \mathrm{g}-\mathrm{VS}_{\text {removed }}$ and $29.7 \mathrm{ml}-\mathrm{H}_{2} / \mathrm{g}-\mathrm{VS}_{\text {added }}$ in average at the food waste proportion of $50 \%$ in VS. However, the hydrogen yield gradually decreased from $100.4 \mathrm{ml}-\mathrm{H}_{2} / \mathrm{g}-\mathrm{VS}_{\text {removed }}$ to $42.3 \mathrm{ml}^{-\mathrm{H}_{2}} / \mathrm{g}-\mathrm{VS}_{\text {removed }}$ in phase IV, implying the performance of biohydrogen anaerobic fermentation process get poor. The stability of fermentation system were hardly to maintain in phase IV and the hydrogen production capacity was lost in phase $\mathrm{V}$, indicating the difficulty of the start-up of biohydrogen production process by food waste fermentation.

The soluble carbohydrate content in the influent and effluent of the fermentation process was shown in Figure 4. In phase II, the shock in OLR and feedstock component resulted to the low removal efficiency in soluble carbohydrate, which might also be the reason for the low hydrogen yield. In phase III and phase IV, the soluble carbohydrate was below $1.9 \mathrm{~g} / \mathrm{l}$ in effluent, indicating great amount of carbohydrate in feedstock was consumed in anaerobic fermentation process. Based on the similar soluble carbohydrate removal efficiency and distinctive hydrogen yield in phase III and phase IV, it could be speculated that the metabolic pathway was converted as the increase of food waste proportion in feedstock.

\section{ACKNOWLEDGMENTS}

This research was financially supported by the College Students' Innovative and Entrepreneurial Training Plan of Tianjin Colleges and Universities (No.201510061037) and Tianjin Research Program of Application Foundation and Advanced Technology (No.16JCQNJC08200).

\section{REFERENCES}

[1] O. Bičáková, P. Straka, Production of hydrogen from renewable resources and its effectiveness, Int. J. of Hydrogen Energ. 37, 11563 (2012).

[2] Y. W. Lee, J. Chung, Bioproduction of hydrogen from food waste by pilot-scale combined hydrogen/methane fermentation, Int. J. of Hydrogen Energ. 35, 11746 (2010).

[3] P. Bakonyi, N. Nemestóthy, V. Simon and K. Bélafi-Bakó. Review on the start-up experiences of continuous fermentative hydrogen producing bioreactors, Renew. Sust. Energ. Rev. 40, 806 (2014).

[4] T. Sreethawong, T. Niyamapa, H. Neramitsuk, P. Rangsunvigit, M. Leethochawalit and S. Chavadej, Hydrogen production from glucosecontaining wastewater using an anaerobic sequencing batch reactor:Effect of COD loading rate, nitrogen content, and organic acid composition, Chem. Eng.J. 160, 322 (2010).

[5] Xinyuan Liu, Ruying Li, Min Ji and Li Han, hydrogen and methane production by co-digestion of waste activated sludge and food waste in the two-stage fermentation process :substrate conversion and energy yield, Bioresour Technol, 146, 317 (2013).

[6] S. Chang, J. Li, F. Liu, Continuous biohydrogen production from diluted molasses in an anaerobic contact reactor, Front. Environ. Sci. Eng. China. 5, 140 (2010).

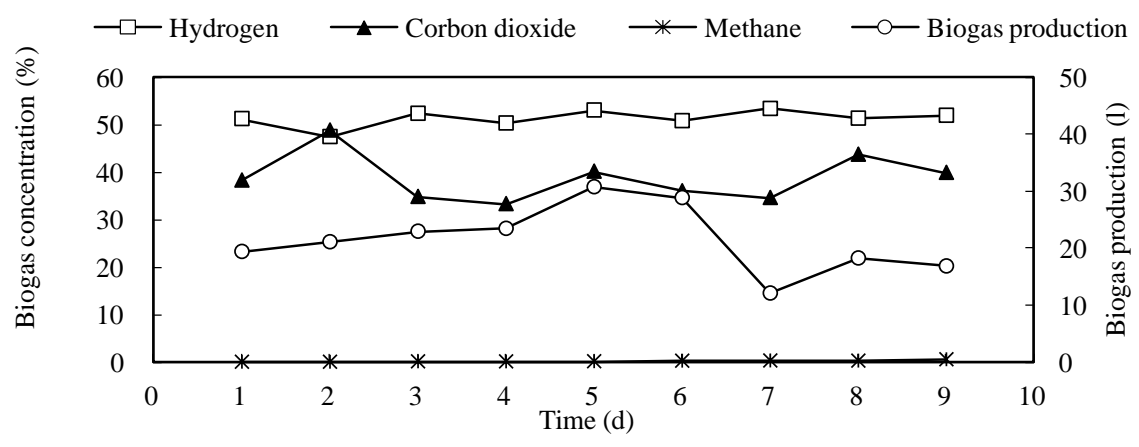

Figure 2. Biogas production and main component concentration for glucose fermentation in phase I.

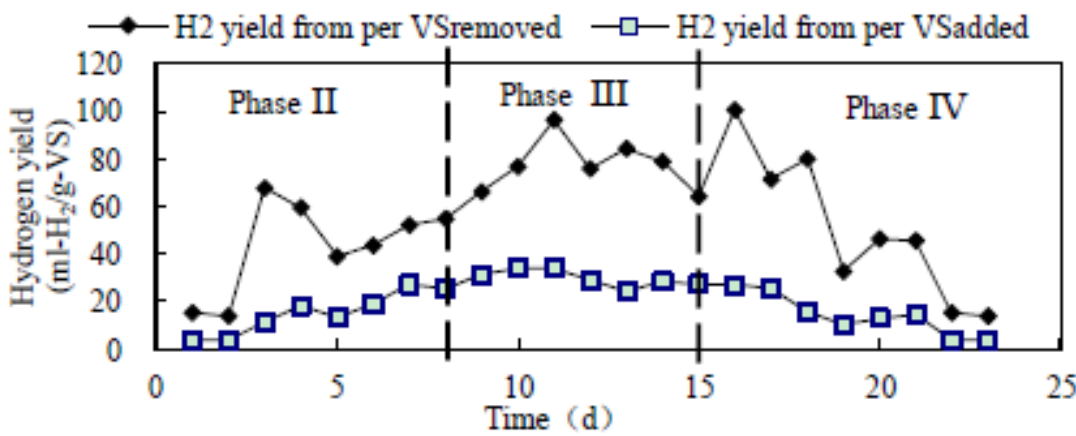

Figure 3. Hydrogen yield during co-fermentation of food waste and glucose in phase II to phase IV. 


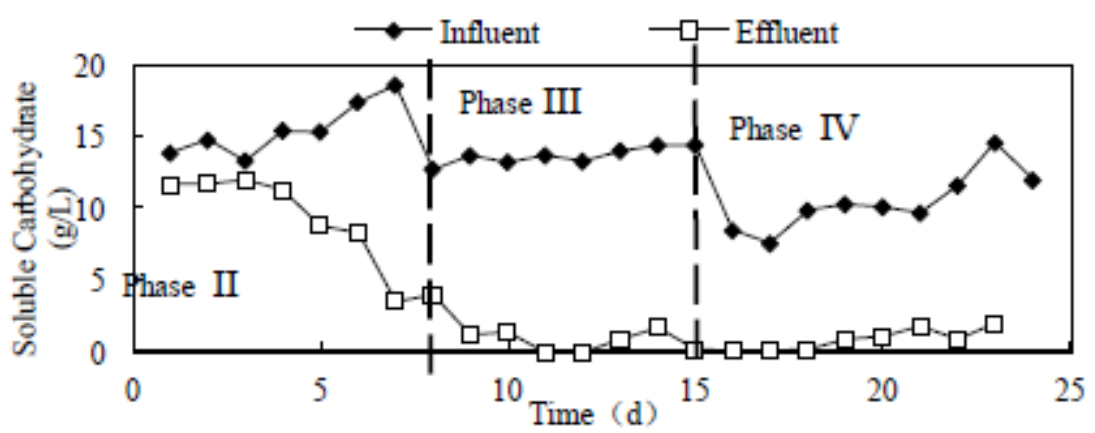

Figure 4. Variation of soluble carbohydrate content in the influent and effluent during co-fermentation of food waste and glucose in phase II to phase IV. 